\title{
Faecal endogenous loss of calcium in young sheep
}

\author{
BY J. S. CHRISP* AND A. R. SYKES† \\ Department of Animal Science, Lincoln College, University of Canterbury, New Zealand \\ AND N. D. GRACE \\ Biotechnology Division, Department of Scientific and Industrial Research, Private Bag, \\ Palmerston North, New Zealand
}

(Received 21 June 1988 - Accepted 3 August 1988)

1. Two groups of eight 6-7-month-old wether lambs were offered either a frozen ryegrass (Lolium perenne L.)-white clover (Trifolium repens L.) pasture or a ryegrass-white clover hay, containing 12.1 and $6.4 \mathrm{~g}$ calcium/ $\mathrm{kg}$ dry matter (DM) respectively. Within groups the amounts offered to individual sheep ranged from 0.5 to 2.0 times the estimated maintenance energy requirements.

2. A single intravenous injection of $150 \mu \mathrm{Ci}^{45} \mathrm{Ca}$ as $\mathrm{CaCl}_{2}, 2 \mathrm{H}_{2} \mathrm{O}$, and stable balances were used to determine absorption, faecal endogenous loss and balance of $\mathrm{Ca}$.

3. Faecal endogenous loss of $\mathrm{Ca}$ increased by $1.2 \mathrm{mg} / \mathrm{kg}$ body-weight $(\mathrm{W}$ ) per $\mathrm{d}$ with each $\mathrm{g} / \mathrm{kg} \mathrm{W}$ per $\mathrm{d}$ increase in DM intake regardless of the diet. At any DM intake the mean faecal endogenous loss was $5.5 \mathrm{mg} / \mathrm{kg} \mathrm{W}$ per $\mathrm{d}$ higher in the sheep offered the frozen herbage diet when compared with those on the hay diet. At any Ca intake the mean faecal endogenous loss was $6.9 \mathrm{mg} / \mathrm{kg} \mathrm{W}$ higher in sheep offered the hay diet compared with those on the frozen herbage.

4. At feeding levels of about $1.5-2$ times the estimated maintenance energy requirement the observed faecal endogenous loss of $\mathrm{Ca}$ ranged from 35 to $50 \mathrm{mg} / \mathrm{kg} \mathrm{W}$ per d, which is two- to threefold greater than the present estimate of the Agricultural Research Council (1980) of $16 \mathrm{mg} / \mathrm{kg} \mathrm{W}$ per d.

5. A simple model to explain the variation in faecal endogenous loss of $\mathrm{Ca}$ between the present study with young sheep and that with lactating ewes (Chrisp et al. 1989) also offered herbage diets is developed, which incorporates the concept of a true endogenous loss related to DM intake and a net endogenous loss reflecting the extent of re-absorption of $\mathrm{Ca}$ endogerous losses within the gastrointestinal tract.

Our understanding of the calcium requirement of ruminants is limited by a lack of knowledge of the factors that influence the endogenous loss of $\mathrm{Ca}$. This is of particular concern with grazing ruminants in pastoral systems because it makes prediction of the amplitude of cycles of body nutrient balance, which are a feature of these systems, extremely difficult. The situation is made more difficult because most of the present information has been obtained from sheep offered cereal-hay-based diets.

The Agricultural Research Council (1980) advocated, from the information then available, the use of a single value for the faecal $\mathrm{Ca}$ endogenous loss of $16 \mathrm{mg} \mathrm{Ca} / \mathrm{kg}$ bodyweight per $\mathrm{d}$. This, however, has been questioned following re-analysis of a substantial body of information by Braithwaite (1982), who proposed that faecal Ca endogenous loss is positively correlated with feed intake. Since these findings were obtained in animals consuming diets of similar composition, the possibility that factors highly correlated with intake, such as the amount of undigested feed residues passing down the gastrointestinal tract, may have influenced the endogenous loss of Ca could not be investigated.

In the present study the faecal endogenous loss of $\mathrm{Ca}$ was determined in lambs offered a highly digestible ryegrass (Lolium perenne L.)-white clover (Trifolium repens L.) herbage and a ryegrass-white clover hay of lower digestibility, at a range of dry matter (DM) intakes.

\footnotetext{
* Present address : Department of Medicine, Concord Repatriation Hospital, Concord, NSW 2139, Australia.

$\uparrow$ For reprints.
} 


\section{EXPERIMENTAL}

\section{Experimental animals and diets}

Sixteen Romney wether lambs, aged 6-7 months, mean body-weight (W) 34 (SD 2.05) kg, were brought indoors into individual metabolism cages, treated with anthelmintic $(5 \mathrm{mg}$ fenbendazole $/ \mathrm{kg} \mathrm{W}$; Panacur; Coopers Animal Health (NZ) Ltd) and given free access to tap water. They were randomly allocated to two groups, one of which was offered frozen ryegrass-white clover herbage with a DM digestibility (DMD) of 0.73 and the other a suncured ryegrass-white clover hay with a DMD of 0.57. Both feeds comprised mixtures of 'Grasslands Ruanui' perennial ryegrass and 'Grasslands Huia' white clover. Within each group individual sheep were randomly allocated to one of eight feeding levels ranging from 0.5 to 2.0 times the estimated maintenance energy requirement. This was calculated on the assumptions that frozen pasture and hay contained 11.0 and $8.4 \mathrm{MJ}$ metabolizable energy (ME) $/ \mathrm{kg} \mathrm{DM}$ respectively, and an animal maintenance requirement of $0.4 \mathrm{MJ} \mathrm{ME} / \mathrm{kg}$ $\mathrm{W}^{0.75}$ per d (Agricultural Research Council, 1980). The actual amount ingested (kg DM/d) ranged from 0.3 to 1.12 for the hay and from 0.34 to 0.92 for frozen pasture (Table 1). Pasture was cut to $10-30 \mathrm{~mm}$ lengths, stored at $-18^{\circ}$, and thawed for $18-24 \mathrm{~h}$ before feeding, while the hay was chopped into $20-30 \mathrm{~mm}$ lengths before feeding. Equal quantities of the ration were offered at 08.30 and 16.30 hours.

\section{Ca kinetic studies}

A $19 \mathrm{~d}$ period for adaptation to feed and metabolism crates was allowed. A single catheter was then fitted in the jugular vein and all animals injected at 11.30 hours with $150 \mu \mathrm{Ci}$ ${ }^{45} \mathrm{Ca}$ as ${ }^{45} \mathrm{CaCl} .2 \mathrm{H}_{2} \mathrm{O}$ (Amersham International plc, Amersham) in $20 \mathrm{ml}$ sterile saline $(9 \mathrm{~g}$ sodium chloride/1). Blood samples were collected at 1, 5, 10 and $20 \mathrm{~min}$ from zero time and subsequently at 20 min intervals until $2 \mathrm{~h}, 2 \mathrm{~h}$ intervals until $12 \mathrm{~h}$, at $18 \mathrm{~h}$ and then $8 \mathrm{~h}$ intervals until $7 \mathrm{~d}$ and $12 \mathrm{~h}$ intervals until $9 \mathrm{~d}$ post-injection. Commencing on the day of injection faeces were collected daily into clean polyethylene bags inserted within collection bags attached to harnesses fitted to the sheep on entry to the metabolism crates. Urine was collected after separation from debris through a sloping nylon-mesh grid.

\section{Analytical methods and the determination of the Ca kinetic variables}

The methods for the preservation of faeces, urine and plasma and their preparation for $\mathrm{Ca}$, $\mathrm{P}$ and $\mathrm{N}$ analysis, the radioisotope counting methods, the model and procedures for the determination of $\mathrm{Ca}$ absorption $\left(V_{a}\right)$, faecal endogenous $\mathrm{Ca}$ loss $\left(V_{f}\right)$ and $\mathrm{Ca}$ balance $(\Delta)$ and the statistical analysis of experimental values have been previously described by Chrisp et al. (1989).

\section{Statistics}

The relations between the faecal endogenous loss of $\mathrm{Ca}$ and DM or the Ca intake were determined by regression analysis.

\section{RESULTS}

\section{Dietary composition}

The mean calcium, phosphorus and nitrogen concentrations (g/kg DM) were $12.2,6.0$ and 37.7 in the frozen ryegrass-white clover herbage and $6.4,3.0$ and 13.9 in the ryegrass-white clover hay respectively.

\section{Ca kinetic studies}

The Ca intake $\left(V_{I}\right)$, loss of $\mathrm{Ca}$ in the faeces $\left(V_{F}\right)$ and urine $\left(V_{u}\right)$ together with $V_{f}, V_{a}$ and $\Delta$ for the lambs offered frozen ryegrass-white clover pasture and hay are given in Table 1. 
Faecal endogenous loss of calcium in sheep

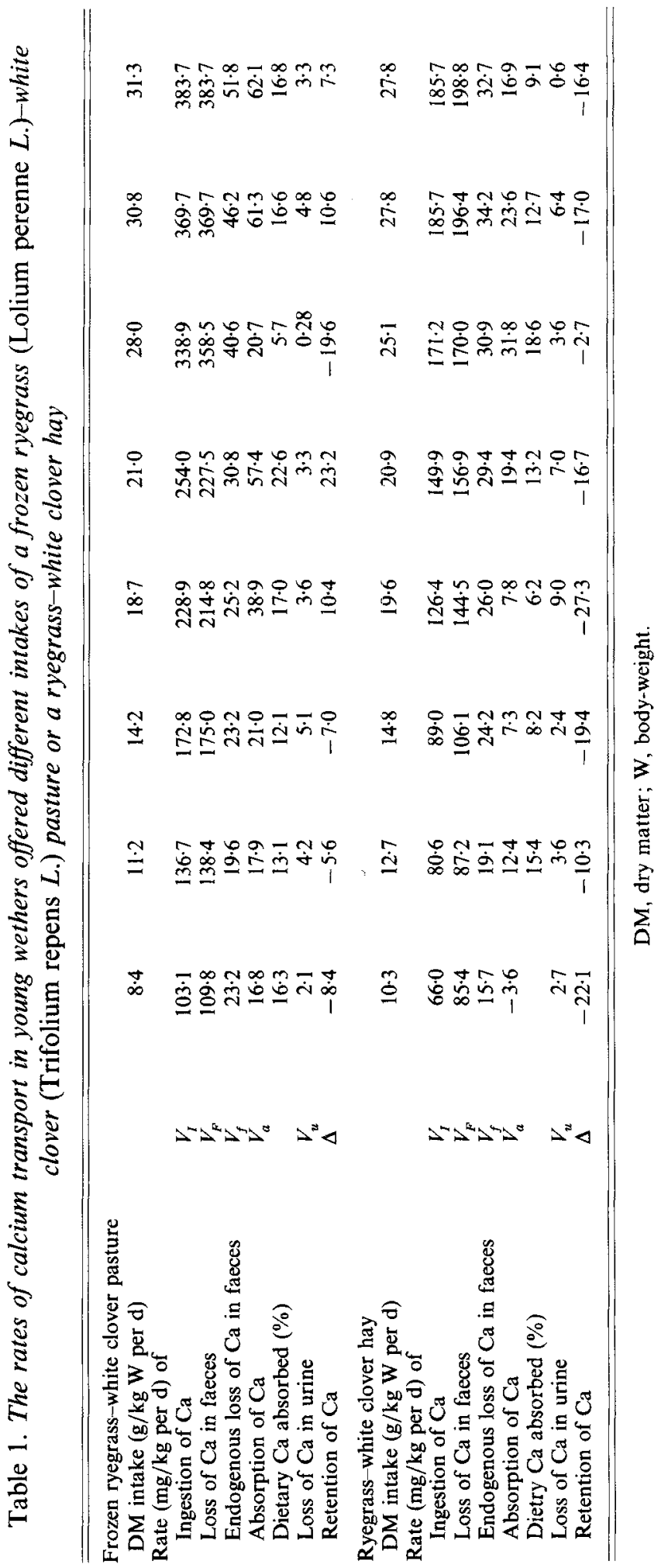


$V_{I}$ ranged from 103.1 to 383.7 and from 66.0 to $185.7 \mathrm{mg} / \mathrm{kg} \mathrm{W}$ per d on the frozen herbage and hay diets respectively. The availability of $\mathrm{Ca}\left(V_{a} / V_{I}\right)$ was low and variable $(0.06-0.22)$ for both diets. All lambs offered the hay diet maintained negative $\mathrm{Ca}$ balances as did the three lambs offered the frozen herbage when DM intake was less than $17.6 \mathrm{~g} / \mathrm{kg} \mathrm{W}$ per $\mathrm{d}$ and $\mathrm{Ca}$ intake less than $175.0 \mathrm{mg} / \mathrm{kg} \mathrm{W}$ per d. Another lamb offered $28.0 \mathrm{~g} \mathrm{DM} / \mathrm{kg} \mathrm{W}$ per $\mathrm{d}$ of this latter diet unaccountably maintained a severely negative $\mathrm{Ca}$ balance. Negative balances were associated with $V_{f}$ which were greater than $V_{a} . V_{u}$ was very low in all animals and was not related to diet or level of intake.

There were significant linear relations within diets between $V_{f}(Y ; \mathrm{mg} / \mathrm{kg} \mathrm{W}$ per d) and either DM intake $\left(X ; \mathrm{g} / \mathrm{kg} \mathrm{W}\right.$ per d) or $V_{I}(Z ; \mathrm{mg} / \mathrm{kg} \mathrm{W}$ per d) where:

$$
\begin{gathered}
Y=8.21+1.22(\mathrm{SE} 0.124) X ; r 0.96, P<0.001, n 8 \\
Y=6.06+0.106(\mathrm{SE} 0.0144) Z ; r 0.96, P<0.001, n 8
\end{gathered}
$$

for the frozen pasture, and

$$
\begin{aligned}
& Y=9.52+0.895(\operatorname{SE} 0.0795) X ; r 0.96, P<0.001, n 8 \\
& Y=9.24+0.132(\operatorname{SE} 0.0138) Z ; r 0.97, P<0.001, n 8
\end{aligned}
$$

for the hay diet.

There were no significant dietary differences in the responses (slopes) relating the faecal endogenous loss of $\mathrm{Ca}$ to $\mathrm{DM}$ or Ca intake. Therefore comparisons on the extent of the effect of diet on the faecal endogenous loss of $\mathrm{Ca}$ were made by comparing the adjusted means of the regressions. For any DM intake the faecal endogenous loss of $\mathrm{Ca}$ was significantly higher $(5.5 \mathrm{mg} / \mathrm{kg} \mathrm{W}$ per $\mathrm{d} ; P<0.01)$ on the frozen ryegrass-white clover compared with the hay diet. For any $\mathrm{Ca}$ intake, the faecal endogenous loss of $\mathrm{Ca}$ was higher $(6.9 \mathrm{mg} / \mathrm{kg} \mathrm{W}$ per $\mathrm{d} ; P<0.05)$ on the hay compared with the frozen ryegrass-white clover diet.

\section{DISCUSSION}

The present findings clearly confirm the observation of Braithwaite (1982) that faecal endogenous loss of $\mathrm{Ca}$ in ruminants is not constant but increases with level of feeding. The values of $35-50 \mathrm{mg} \mathrm{Ca} / \mathrm{kg} \mathrm{W}$ per $\mathrm{d}$ at levels of feeding of about $1 \cdot 5-2$ times the maintenance energy requirement are up to three times greater than estimates of the Agricultural Research Council (1980) of $16 \mathrm{mg} \mathrm{Ca} / \mathrm{kg} \mathrm{W}$ per $\mathrm{d}$ and are $50-70 \%$ higher than values previously observed in growing sheep (Braithwaite, 1982; Field et al. 1985) and in pregnant and lactating ewes (Braithwaite, 1982; Chrisp et al. 1989).

It is not possible to determine precisely the factors determining endogenous loss of $\mathrm{Ca}$ because $\mathrm{Ca}$ and DM intakes were confounded in comparisons of the diets. Nevertheless the findings do allow the conclusion that, despite the strong relation with level of feeding, endogenous loss is unlikely to be determined uniquely by either intake of DM or Ca. This is the case because there were significant trends for greater endogenous losses $(+5.5 \mathrm{mg} /$ $\mathrm{kg} \mathrm{W}$ per d) on the frozen grass than on the hay at the same DM intake and vice versa $(+6.6 \mathrm{mg} / \mathrm{kg} \mathrm{W}$ per d) when compared at the same Ca intake. This subject is developed further at a later stage. It is, moreover, possible to suggest that the quantity of indigestible DM passing down the digestive tract is of little significance in determining endogenous loss, since at the same values for indigestible DM intake, calculated from DM intakes (Table 1), and the digestibility values of the frozen grass and hay ( 0.73 and 0.57 respectively), faecal endogenous loss of Ca was, on average, almost $15 \mathrm{mg} / \mathrm{kg} \mathrm{W}$ per $\mathrm{d}$ greater on the frozengrass diet.

The present values, the only ones reported for young growing animals consuming 

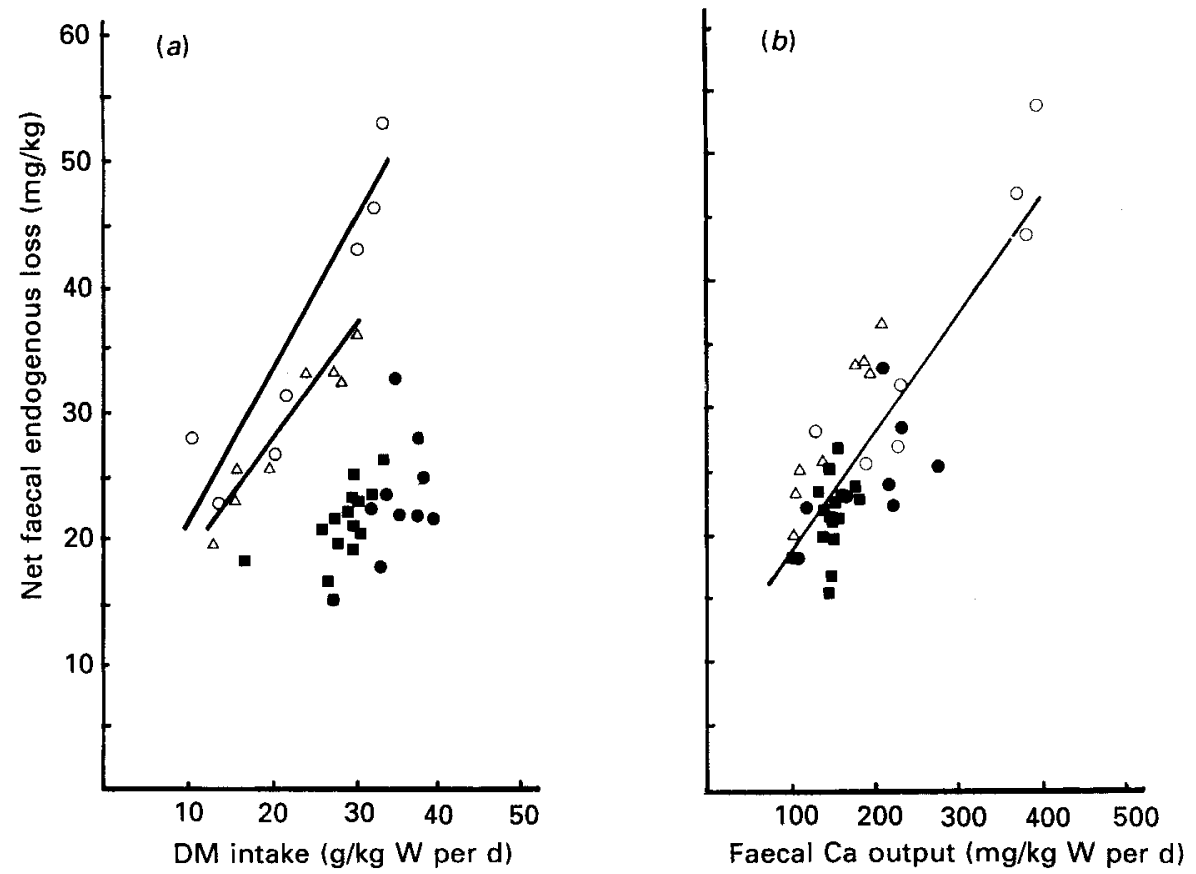

Fig. 1. The relation between net faecal endogenous loss of calcium ( $\mathrm{mg} / \mathrm{kg}$ body-weight per $\mathrm{d}$ ) and (a) dry matter intake $(\mathrm{g} / \mathrm{kg} \mathrm{W}$ per d) or $(b)$ faecal Ca output $(\mathrm{mg} / \mathrm{kg} \mathrm{W}$ per d) from the present lambs consuming fresh $(O)$ or conserved $(\triangle)$ herbage (ryegrass (Lolium perenne L.) - white clover (Trifolium repens L.)) and those of Chrisp et al. (1989) for lactating sheep consuming fresh herbages ( $\square, O$ ).

herbage diets, are not only higher than most recorded in the literature but are also very high compared with values obtained by Chrisp et al. (1989) in this laboratory in lactating sheep consuming similar diets. These latter values, together with the present findings have been brought together in Fig. 1. The discrepancy between the two sets of values, when endogenous loss $(\mathrm{mg} \mathrm{Ca} / \mathrm{kg} \mathrm{W}$ per d) is expressed in relation to DM intake $(\mathrm{g} / \mathrm{kg} \mathrm{W}$ per d) in Fig. $1(a)$ raises the question as to whether endogenous loss of $\mathrm{Ca}$ is, in fact, greater in young than in adult sheep. On the other hand, when the findings are compared in relation to $\mathrm{Ca}$ intake or faecal $\mathrm{Ca}$ output $(\mathrm{mg} \mathrm{Ca} / \mathrm{kg} \mathrm{W}$ per $\mathrm{d}$ in both cases) much closer relations are observed amongst the present sheep and the lactating sheep of Chrisp et al. (1989). Examination of the pooled values by linear regression analysis showed that whereas DM intake $(\mathrm{g} / \mathrm{kg} \mathrm{W}$ per $\mathrm{d})$ explained only $\mathrm{i} 2 \%$ of the variation in endogenous loss $(\mathrm{mg} \mathrm{Ca} /$ $\mathrm{kg} \mathrm{W}$ per d) $\mathrm{Ca}$ intake and faecal Ca output explained 72 and $83 \%$ respectively. This latter relation is described in Fig. $1(b)$.

There may be sound physiological reasons for a closer relation between endogenous $\mathrm{Ca}$ losses and faecal $\mathrm{Ca}$ for the following reasons.

The amount of $\mathrm{Ca}$ absorbed is strictly regulated in the ruminant according to its net $\mathrm{Ca}$ requirement. Intravenous infusion of $\mathrm{Ca}$, for example, causes a reduction in the rate of $\mathrm{Ca}$ absorption rather than a change in the endogenous loss of $\mathrm{Ca}$ (Braithwaite, 1978). The isotope-dilution technique, moreover, measures a net endogenous loss of $\mathrm{Ca}$, and not necessarily the true endogenous loss, as some of the $\mathrm{Ca}$ secreted into the digestive tract could be re-absorbed. Net and true endogenous losses would be the same if the sites of $\mathrm{Ca}$ secretion were distal to the sites of absorption or if the endogenously secreted $\mathrm{Ca}$ was 


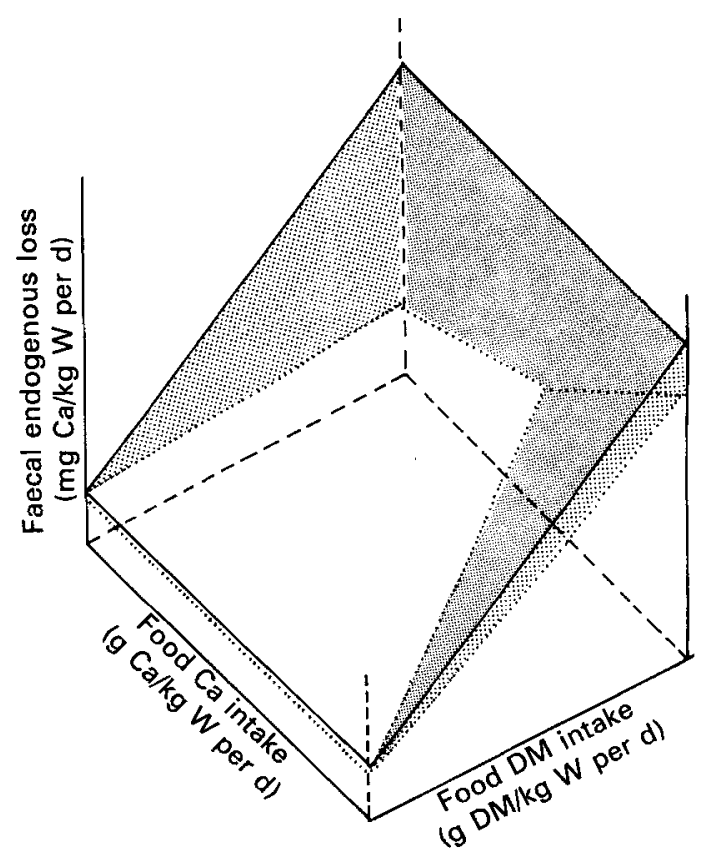

Fig. 2. A schematic representation of the proposed relation between dietary factors influencing true (-) and net (.....) faecal endogenous loss of calcium. (图, 国). The proportion of true endogenous loss which is re-absorbed. It describes a simple relation between true endogenous loss and food dry matter (DM) intake with a variable net faecal endogenous loss which is dependent on net Ca requirement in relation to the $\mathrm{Ca}$ intake or the amount of $\mathrm{Ca}$ available for absorption in the alimentary tract. W, bodyweight.

totally unavailable for absorption. There is good evidence in the sheep for net absorption of $\mathrm{Ca}$ occurring not only from the small intestine but also from the hind-gut (Pfeffer et al. 1970; Grace et al. 1974; Bown, 1986). Further, recent studies in which ${ }^{45} \mathrm{Ca}$ was infused into the terminal ileum (Cottle, Poppi \& Sykes, unpublished results) have provided direct evidence for $\mathrm{Ca}$ absorption in the large intestine. This is perhaps surprising in view of the decrease in solubility of $\mathrm{Ca}$ from 85 to $30 \%$ with increasing $\mathrm{pH}$ between the duodenum and terminal ileum (Ben-Ghedalia et al. 1975); however, these workers did observe that $60 \%$ of $\mathrm{Ca}$ in faeces was soluble.

On the assumption that endogenously secreted $\mathrm{Ca}$ is available for absorption, the size of the pool of absorbable $\mathrm{Ca}$ in the gastrointestinal tract, both from exogenous and endogenous sources, and the net $\mathrm{Ca}$ requirement of the animal will influence the proportion of the endogenous loss which is reabsorbed. When the demand for Ca is high and the pool of absorbable $\mathrm{Ca}$ is small, a greater proportion of the endogenously secreted $\mathrm{Ca}$ might be expected to be re-absorbed, and therefore the net faecal endogenous loss of $\mathrm{Ca}$ would be much less than the true endogenous loss. When the $\mathrm{Ca}$ demand is low and the absorbable $\mathrm{Ca}$ pool large, net and true endogenous $\mathrm{Ca}$ loss would be expected to be similar.

The higher net endogenous loss of $\mathrm{Ca}$ in the growing lambs offered the frozen herbage than in those offered the hay, particularly at high intakes, may reflect the larger pool of Ca in the gastrointestinal tract or a lower availability of endogenous and exogenous, $\mathrm{Ca}$, or both. On the other hand, the lower net endogenous loss of $\mathrm{Ca}$ in the lactating sheep than in the lambs at the same intake of DM or of $\mathrm{Ca}(\mathrm{g} / \mathrm{kg} \mathrm{W}$ per d) may reflect their much 
greater demand for $\mathrm{Ca}$ from the pool in the alimentary tract, and therefore a greater reabsorption of true endogenous secretions of $\mathrm{Ca}$. A model is proposed to describe the relation between true and net faecal endogenous loss of $\mathrm{Ca}$ with changes in the DM intake and the amount of $\mathrm{Ca}$ available for absorption and is illustrated in Fig. 2.

This envisages that true faecal endogenous loss of $\mathrm{Ca}$ increases with increasing food DM intake regardless of the size of the absorbable $\mathrm{Ca}$ pool (though determined by Ca intake). For a given DM intake and for a given net $\mathrm{Ca}$ requirement, decreasing the pool size of absorbable $\mathrm{Ca}$ in the gastrointestinal tract ( $\mathrm{Ca}$ intake $\times \mathrm{Ca}$ availability) may not affect true faecal endogenous loss of $\mathrm{Ca}$ but is likely to widen the difference between the true and net endogenous loss. An increase in net $\mathrm{Ca}$ requirement at a given DM intake and pool size of available $\mathrm{Ca}$ would have similar consequences.

The traditional approach to the estimation of the net endogenous loss of $\mathrm{Ca}$ may be an over-simplification of the true physiological situation. There is clearly a need to quantify those factors which influence the endogenous loss of $\mathrm{Ca}$ including the relation between exogenous and endogenous $\mathrm{Ca}$ in the digestive tract, the availability of endogenous $\mathrm{Ca}$ for absorption, and the ability of the hind-gut to transport $\mathrm{Ca}$.

The authors are grateful to Miss S. Bos, Messrs N. P. Jay, M. Lamming and P. Lord for assistance with the animals and to Mrs P. Wilson, Miss P. Gibb and Messrs G. Elmsly and J. Thackwell for assistance with laboratory analysis. J.S.C. gratefully acknowledges the receipt of a Department of Scientific and Industrial Research Postgraduate Scholarship.

\section{REFEREN CES}

Agricultural Research Council (1980). The Nutrient Requirements of Ruminant Livestock. Slough : Commonwealth Agricultural Bureaux.

Ben-Ghedalia, D., Tagari, H., Zamwel, S. \& Bondi, A. (1975). Solubility and net exchange of calcium, magnesium and phosphorus in digesta flowing along the gut of sheep. British Journal of Nutrition 33, 87-94.

Bown, M. D. (1986). Protein metabolism in parasite infected lambs. PhD Thesis, University of Canterbury, New Zealand.

Braithwaite, G. D. (1978). Adaptations in the calcium and phosphorus metabolism of sheep in response to an intravenous infusion of Ca. British Journal of Nutrition 40,17-21.

Braithwaite, G. D. (1982). Endogenous faecal loss of calcium by ruminants. Journal of Agricultural Science, Cambridge 99, 355-358.

Chrisp. J. S., Sykes, A. R. \& Grace, N. D. (1989). Kinetic aspects of calcium metabolism in lactating sheep offered herbages with different $\mathrm{Ca}$ concentrations and the effect of protein supplementation. British Journal of Nutrition 61, $45-58$

Field, A. C., Woolliams, J. A. \& Dingwall, R. A. (1985). The effect of dietary intake of calcium and dry matter on the absorption and excretion of calcium and phosphorus by growing lambs. Journal of Agricultural Science, Cambridge 105, 237-243.

Grace, N. D., Ulyatt, M. J. \& MacRae, J. C. (1974). Quantitative digestion of fresh herbage by sheep. III. The movement of $\mathrm{Mg}, \mathrm{Ca}, \mathrm{P}, \mathrm{K}$ and $\mathrm{Na}$ in the digestive tract. Journal of Agricultural Science, Cambridge 82, $321-330$

Pfeffer, E., Thompson, A. \& Armstrong, D. G. (1970). Studies on intestinal digestion in sheep. 3. Net movement of certain inorganic elements in the digestive tract on rations containing different proportions of hay and rolled barley. British Journal of Nutrition 24, 197-204. 